NASA Technical Memorandum 107317

AIAA-96-2598

\title{
Rhenium Mechanical Properties and Joining Technology
}

Brian D. Reed and James A. Biaglow

Lewis Research Center

Cleveland, Ohio

Prepared for the

32nd Joint Propulsion Conference

cosponsored by AIAA, ASME, SAE, and ASEE

Lake Buena Vista, Florida, July 1-3, 1996

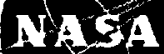

National Aeronautics and

Space Administration 


\title{
RHENIUM MECHANICAL PROPERTIES AND JOINING TECHNOLOGY
}

\author{
Brian D. Reed and James A. Biaglow \\ National Aeronautics and Space Administration \\ Lewis Research Center \\ Cleveland, Ohio 44135
}

\begin{abstract}
Iridium-coated rhenium ( $\mathrm{Ir} / \mathrm{Re}$ ) provides thermal margin for high performance and long life radiationcooled rockets. Two issues that have arisen in the development of flight $\mathrm{Ir} / \mathrm{Re}$ engines are the sparsity of rhenium (Re) mechanical property data (particularly at high temperatures) required for engineering design and the inability to directly electron beam weld Re chambers to $\mathrm{C} 103$ nozzle skirts. To address these issues, a $\operatorname{Re}$ mechanical property database is being established and techniques for creating $\mathrm{Re} /$ C103 transition joints are being investigated. This paper discusses the tensile testing results of powder metallurgy Re samples at temperatures from 1370 to $2090^{\circ} \mathrm{C}$. Also discussed is the evaluation of $\mathrm{Re} / \mathrm{Cl} 103$ transition pieces joined by both, explosive and diffusion bonding. Finally the evaluation of full size $\mathrm{Re}$ transition pieces, joined by inertia welding, as well as explosive and diffusion bonding, is detailed.
\end{abstract}

\section{INTRODUCTION}

The key to high performance and long lifetimes for radiation-cooled rockets is the chamber material. The material system currently used for radiationcooled rockets is a niobium alloy (C103) with a disilicide coating (R512E). Because of the thermal limitations of the coating, C103 rockets have a useful maximum operating temperature of $1370{ }^{\circ} \mathrm{C}$. In order to keep the wall temperature under the thermal limits of the material, fuel film cooling (FFC) is typically employed. FFC significantly degrades rocket performance and, in some cases, imposes a plume contamination issue. A material system composed of a rhenium ( $R e$ ) substrate and an iridium (Ir) coating has been used to demonstrate high-temperature $\left(2200{ }^{\circ} \mathrm{C}\right)$, long-life (hours) operation for radiationcooled rockets using Earth storable propellants (refs. 1 and 2). The added thermal margin afforded by iridium-coated rhenium (Ir/Re) allows the reduction or elimination of fuel film cooling, which promotes more efficient combustion. Higher combustion efficiency results in increased engine performance and reduced plume contamination from unburned fuel.

There are currently both government- and industry-sponsored efforts to develop flight $\mathrm{Ir} / \mathrm{Re}$ engines, and, to date, the major focus is on $440-\mathrm{N}$, apogee insertion applications. Specific concerns and issues associated with $\mathrm{Ir} / \mathrm{Re}$ engines are being addressed in these development efforts, including: (1) low cost, reliable $\mathrm{Ir} / \mathrm{Re}$ rocket fabrication methods; (2) development of critical Re mechanical property data; (3) development of reliable, low cost methods of joining $\mathrm{Re}$ chambers to dissimilar metals; and (4) characterization of Ir/Re life limiting mechanisms.

This paper is a follow-on to previous papers that discussed the mechanical properties of various $\mathrm{Re}$ manufactured forms (ref. 3) and the evaluation methods of joining $\operatorname{Re}$ to dissimilar metals (ref. 4). As part of the on-going effort to establish a $\mathrm{Re}$ mechanical property database, tensile testing results of hot isostatic pressure (HIP) powder metalurgy (PM) Re samples at temperatures up to $2090{ }^{\circ} \mathrm{C}$ will be presented. Also the shear testing of $\mathrm{Re} / \mathrm{C} 103$ joint coupons, completing an evaluation that was started in a previous paper (ref. 4) will be presented.

\section{BACKGROUND}

\section{Rhenium Mechanical Properties}

In order to efficiently design and integrate $\mathrm{Ir} / \mathrm{Re}$ engines for spacecraft applications, the mechanical properties of $\operatorname{Re}$ must be better understood. The engines (often cantilevered) must both survive launch-induced stresses and be capable of repeated on-orbit firings. The material property database for $\mathrm{Re}$ is sparse. Further, reported data often does not include the fabrication or material history crucial to interpreting and applying the data. An effort is in progress to establish an extensive $\operatorname{Re}$ mechanical properties database for use in the design and manufacture of high performance $\mathrm{Ir} / \mathrm{Re}$ engines.

A previous study (ref. 3) evaluated four manufactured forms of Re in tensile and low cycle fatigue testing at temperatures up to $1370{ }^{\circ} \mathrm{C}$ and in creep testing at $1650^{\circ} \mathrm{C}$. Re samples fabricated by chemical vapor deposition (CVD), pressed and sintered PM, rolled sheet PM, and HIP PM were evaluated. CVD is the established process for fabricating $\mathrm{I} / \mathrm{Re}$ chambers (refs. 1 and 2). A PM Re substrate with an electroformed deposited Ir coating, is being considered as an alternative fabrication process (ref. 5). The results showed that $\mathrm{Re}$ properties varied considerably among the different manufactured forms and 
that selection of a $\mathrm{Re}$ fabrication process and its material history will dictate its properties.

\section{Joining of Rhenium to Dissimilar Metals}

Ir $/ \mathrm{Re}$ chambers need to be joined to injectors and nozzle skirts. Common injector materials include 304L stainless steel, titanium, and C103. In state of art rockets, the $\mathrm{C103}$ substrate is used from the chamber to the nozzle. However, since Re is a heavy material and high temperature capability is not needed downstream of the throat region, $\mathrm{Re}$ engines will employ $\mathrm{C} 103$ nozzle skirts. The injector-tochamber and the chamber-to-nozzle joints are typically designed not to bear major mechanical loads, so the primary requirement for the joints would be adequate sealing over life. Both joints are subjected to thermal cycling from about $25^{\circ} \mathrm{C}$ to a maximum of $1370{ }^{\circ} \mathrm{C}$, with the number and duration of the thermal cycles dependent on the application.

Electron beam (EB) welding of $\mathrm{Re}$ to $\mathrm{C} 103$ has resulted in brittle joints due to the formation of a $\mathrm{Re}$ niobium $(\mathrm{Nb})$ sigma phase (refs. 6 and 7). This brittle intermetallic phase, which forms above $2162^{\circ} \mathrm{C}$, precludes the use of fusion methods in directly joining $\operatorname{Re}$ to $\mathrm{C} 103$. Brazing has been used to join $\operatorname{Re}$ to C103. The brazing process often requires a complex design at the interfaces, however, to assure proper wetting of the joining area. Braze layers also have limited strength, temperature, and thermal cycling capabilities.

An alternative to brazing is the use of a bi-metal transition joint composed of $\mathrm{Re}$ and $\mathrm{Cl03}$, formed by nonfusion methods. The $R e$ chamber can be EB welded to the $\mathrm{Re}$ side of the joint and the $\mathrm{C} 103$ nozzle skirt EB welded to the $\mathrm{C} 103$ side. A transition ring was formed for a 440-N Re engine by deposition of CVD $\mathrm{Nb}$ onto $\mathrm{Re}$ and $\mathrm{C} 103$ pieces. The engine was tested for 80 full thermal cycles and over $6 \mathrm{hr}$, at joint temperatures up to $1166^{\circ} \mathrm{C}$ (ref. 8).

Other nonfusion joining methods of forming transition pieces include diffusion bonding, explosive bonding, and inertia welding. In diffusion bonding, heat and pressure are applied uniformly to expand one piece into the other. Explosive bonding is a cold welding process that uses controlled explosive detonations to join two pieces. Inertia welding uses the stored energy in a flywheel to impart a piece into a stationary piece. In each of these joining methods the formation of a brittle $\mathrm{Re}-\mathrm{Nb}$ intermetallic is avoided because bond line temperatures never reach $2162{ }^{\circ} \mathrm{C}$.

A previous paper (ref. 4) reported on the evaluation of flat plate $\mathrm{Re} / \mathrm{Cl03}$ coupons of explosively- and diffusion-bonded joints. Flat plate coupons were used as an inexpensive way of determining the integrity of the joining technique. Successful results would warrant further testing with full size joints. The joint coupons were evaluated in a series of tests, where shear strength was used as a figure of merit for the integrity of the coupon. Not all of the samples had been tested at the time of that report, however. This paper describes the completion of the flat plate joint evaluation study, presenting the data from both reports. This paper will also discuss the evaluation of $\mathrm{Re} / \mathrm{ClO3}$ ring coupons joined by diffusion bonding. Testing (conducted under a NASA contract) of full size transition pieces joined by inertia welding, diffusion bonding, and explosive bonding will be reported as well.

\section{RHENIUM TENSILE TESTING AT ELEVATED TEMPERATURES}

\section{Test Procedure}

HIP PM Re pieces (density greater than 99 percent) were obtained from Rhenium Alloys, Inc. The $\mathrm{Re}$ pieces were electron discharged machined (EDM) into the bar bell configuration shown in figure 1. The samples were acid scrubbed to remove any melt or recrust from the EDM process and then acid washed to remove any contaminants.

High temperature tensile testing of the HIP PM Re samples was conducted both by NASA and AlliedSignal, Fluid Systems Division. To assure consistency of data, the same preparations and test procedures used in the previous study (ref. 3) were followed in this testing. Tensile testing was conducted at temperatures from 1370 to $2090^{\circ} \mathrm{C}$, providing 0.2 percent yield strength, ultimate strength, percent reduction of area, and percent elongation data.

\section{Results and Discussion}

The results of the tensile test data, both at NASA and AlliedSignal, are presented in table I. The 0.2 percent yield and ultimate strength data are plotted in figure 2 . There was generally good agreement between the NASA and AlliedSignal data. There was a significant dropoff in strength from 1370 to $2090{ }^{\circ} \mathrm{C}$, as would be expected. However, 0.2 percent yield strength values were 67 to $78 \mathrm{MPa}$ at $1925^{\circ} \mathrm{C}$. These yield strength values are comparable to those for $\mathrm{C} 103$ at lower temperatures $\left(1370^{\circ} \mathrm{C}\right)$ and are adequate for rocket operation.

The HIP PM Re tensile data indicated behavior similar to what would be expected of a brittle material. The 0.2 percent yield values were generally within 5 to 10 percent of the ultimate strength values. Furthermore, the percent reduction of area and percent elongation values were, for the most part, low for a ductile material. This is consistent with observations from the previous testing conducted below $1370{ }^{\circ} \mathrm{C}$ (ref. 3), in which annealed HIP PM Re samples exhibited a sharp, brittle-like failure. 


\section{EVALUATION OF RHENIUM-TO-C103 JOINTS}

\section{Evaluation Procedure}

Two Re-to-C103, explosively-bonded plates, each approximately 5.1 by 15 by $1.1 \mathrm{~cm}$, were received from Northwest Technical Industries (NTI). The $\mathrm{Re}$ thickness was approximately $0.64 \mathrm{~cm}$, while the $\mathrm{C} 103$ was $0.48 \mathrm{~cm}$ thick. The two plates represented differences in the parameters used in the explosive bond process and were labeled lot \#2090 and lot \#2097, respectively. Lot \#2097 used lower energy parameters for bonding than lot \#2090. Two Re-to-C103, diffusion-bonded plates, each 5.1 by 2.2 by $0.80 \mathrm{~cm}$, were received from Advanced Methods and Materials (AMM). The Re thickness was approximately $0.32 \mathrm{~cm}$, while the $\mathrm{C} 103$ was $0.48-\mathrm{cm}$ thick. Each plate was fabricated using the same process parameters. A diffusion-bonded tube with a C103 exterior and a $\mathrm{Re}$ interior was also provided by AMM.

Each of the explosively-bonded and diffusionbonded plates were sectioned into sandwich and " $Z$ " coupon configurations, as shown in figure 3 . Sandwich coupons were used for the $\mathrm{EB}$ welding of $\mathrm{Re}$ and $\mathrm{C} 103$ tabs before being cut into $\mathrm{Z}$ coupons. The diffusion-bonded tube was sectioned into ring shear samples, as shown in figure 4.

Joint coupon shear testing and analyses were performed at the University of Dayton. In order to assess the integrity of the joints, the flat plate coupons were shear tested under the following conditions:

- As-received

- After being subjected to 100 thermal cycles from 100 to $1100^{\circ} \mathrm{C}$

- After the addition of a Re and/or C103 EB weld tab

- After the addition of a Re and/or C103 EB weld tab and being subjected to 100 thermal cycles from 100 to $1100^{\circ} \mathrm{C}$

Thermal cycling was performed to assess the integrity of the joint during an operational cycle. Thermal cycling of coupons was conducted by placing them in an evacuated quartz vessel. The vessel was heated in a furnace to $1100^{\circ} \mathrm{C}$ (the maximum capability of the furnace) and immediately cooled to $100{ }^{\circ} \mathrm{C}$ by quenching the vessel in water. The diffusion-bonded flat plate coupons were also subjected to thermal aging in an evacuated furnace at $1100^{\circ} \mathrm{C}$.

The addition of $\mathrm{Re}$ and/or C103 EB weld tabs to coupons was performed to simulate the incorporation of the transition joint in a rocket. Full penetration was achieved on the EB welds.
Ultimate shear strength was used as a figure of merit for comparison between coupons. For shear testing, the coupons were pushed against a fixture (as shown in fig. 5) in order to reduce bending moments that may have resulted from pulling the coupon.

\section{Results and Discussion}

The shear test results from the explosively- and diffusion-bonded joint coupons are summarized (in bold print) in tables II and III, respectively. The data generated from this study is presented along with the data (in plain print) from the previous study (ref. 4) to present a whole picture of the joint evaluation. The shear test results for the explosively-bonded coupons are plotted in figures 6 to 9 , while the diffusionbonded coupon results are shown in figures 10 to 12 . The results demonstrated the integrity of explosive and diffusion bonding for joining $\operatorname{Re}$ to C103.

\section{Explosively-Bonded Coupons}

Thermal cycling by itself did not appear to significantly degrade the strength of the explosivelybonded coupons (fig. 6). The same results were found when EB weld tabs, whether Re or C103, were added to the coupons (fig. 7). The cycled and weld tab coupons generally had shear strength values in the range of the as-received coupons. The shear test results indicated that thermal cycling alone and the addition of EB weld tabs alone did not degrade the integrity of the joint.

The combination of adding C103 EB weld tabs and thermally cycling, however, resulted in significant loss of shear strength from the as-received coupons (figs. 8 and 9). Strength also degraded for the thermally-cycled coupons that had both $\operatorname{Re}$ and C103 EB weld tabs. One of the three thermallycycled coupons with $\mathrm{Re}$ EB weld tabs had degraded strength. The shear tests results for these coupons indicated that the cumulative effect of cycling and welding C103 tabs degraded the integrity of the joint.

To investigate the loss of strength in the cycled/ C103 tab coupons further, the fracture surfaces of two explosively-bonded coupons (lot \#2090) were examined. Both coupons had C103 EB weld tabs. One of the coupons was not thermally-cycled and exhibited high shear strength (403 MPa shear strength) comparable to as-received coupons. The other coupon was thermally-cycled, obtaining relatively low shear strength (114 MPa shear strength). The concentration versus depth profiles of Re-side fracture surfaces of these coupons were determined, using Auger electron spectroscopy (AES) combined with a ball-cratering technique. In this technique, a $3-\mathrm{cm}$ diameter stainless steel ball, covered with a $1-\mu \mathrm{m}$ diamond paste was used to wear a $16-\mu \mathrm{m}$ crater in the fracture 
surface of the coupon. An AES line scan was performed along the crater wall and converted into a profile of concentration versus depth. The concentration profile is an estimate, since a $\mathrm{Re}-\mathrm{Nb}$ alloy standard of known composition was not used (ref. 9).

Figure 13 shows the depth profile of the coupon that was not thermally-cycled. The profile shows a high concentration of $\mathrm{Nb}$ and a relatively low amount of $\operatorname{Re}$ at depths to $8 \mu \mathrm{m}$. (Carbon and iron signals were present from the stainless steel ball used to create the crater). At a depth of about $9 \mu \mathrm{m}$, there was a sharp decrease in $\mathrm{Nb}$ concentration and sharp increase in $\mathrm{Re}$ concentration. This profile indicates that the coupon fractured in the bulk $\mathrm{Nb}$ rather than at the joint. The sharp transition at $9 \mu \mathrm{m}$, indicated that there was little $\mathrm{Re} / \mathrm{Nb}$ interdiffusion.

Figure 14 shows the depth profile of the coupon which had a C103 EB weld tab and was thermallycycled. From this it can be seen that nearly equal concentrations of $\mathrm{Re}$ and $\mathrm{Nb}$ were present to a depth of about $7 \mu \mathrm{m}$. At greater depths, the $\mathrm{Nb}$ concentration gradually decreased. This profile indicates the presence of a $\mathrm{Re}-\mathrm{Nb}$ alloy at the fracture surface. This alloy would seem to be responsible for the coupon's degraded strength, although it does not appear to be the brittle intermetallic identified in previous $\operatorname{Re}$ joining studies (refs. 6 and 7).

The combination of thermal cycling and EB welding C103 tabs apparently caused a $\mathrm{Re}-\mathrm{Nb}$ alloy that significantly degraded joint strength. Re-Nb interdiffusion (a temperature-driven process) evidently occurred both during the EB welding of tabs and during the thermal cycling. The thermal conductivity of $\mathrm{Cl03}$ is lower than $\mathrm{Re}$, so the problem would be more acute during the EB welding of $\mathrm{C} 103$ tabs. Each process alone, however, was not sufficient to create the $\mathrm{Re}-\mathrm{Nb}$ alloy that degraded joint strength. The amount of $\mathrm{Re}-\mathrm{Nb}$ interdiffusion during EB welding could be reduced or eliminated if a larger heat sink were provided. This would lessen the effects of the interdiffusion that occurs during thermal cycling.

\section{Diffusion-Bonded Coupons}

For the diffusion-bonded flat plate coupons, there appeared to be a decrease in strength from the asreceived coupons to the thermally-cycled and thermally-aged coupons (fig. 10). With only one thermally-cycled coupon, however, it is difficult to draw any conclusions.

The small number of coupons also make it difficult to assess the effects of the EB weld tabs on the joint strength (fig. 11). As was the case for the explosively-bonded coupons, the addition of $\mathrm{C} 103$ EB weld tabs alone did not result in any significant loss of strength. The same was true for the thermallycycled coupons with a $\operatorname{Re} \mathrm{tab}$ and both $\operatorname{Re}$ and $\mathrm{C} 103$ tabs. However, one of the two thermally-cycled coupons with $\mathrm{C} 103$ tabs experienced a significant loss in strength.

Diffusion-bonded ring coupons gave a more realistic assessment of the joining technique than flat plates. Thermally-cycled coupons had shear strength values within the scatter of the as-received coupons (fig. 12). The thermally-aged coupon, in fact, had significantly higher strength than the as-received coupons, but again, caution must be taken from drawing conclusions from one data point.

\section{TRW Rhenium Joint Evaluation}

TRW evaluated inertia-, diffusion-, and explosively-bonded joint coupons under the NASAsponsored Space Storable Rocket Technology program (ref. 10). This work is summarized in table IV. $\mathrm{Re}$ was not directly bonded to $\mathrm{C} 103$, because there was concern that diffusion of $\mathrm{Hf}$ from $\mathrm{C} 103$ into $\mathrm{Re}$ would result in a brittle $\mathrm{Hf}-\mathrm{Re}$ intermetallic phase. Re was joined to $\mathrm{Nb}-7.5$ tantalum ( $\mathrm{Ta}$ ) for the inertia weld coupons, while $\operatorname{Re}$ was joined to pure Ta for the diffusion bond coupon. For the explosive bond coupons, a $\mathrm{Ta}$ interlayer was used in joining $\operatorname{Re}$ to C103.

Inertia-welded, $\mathrm{Re} / \mathrm{Nb}-7.5 \mathrm{Ta}$ rods were found to have high strength (299 MPa ultimate shear strength) after being subjected to 2 hours at $1370{ }^{\circ} \mathrm{C}$. Full-size rings (simulating the injector-to-chamber joint) were found to be leak tight (to $2 \mathrm{MPa}$ ) after $2 \mathrm{hr}$ at $1370^{\circ} \mathrm{C}$ and 30 thermal cycles of room temperature to $1370{ }^{\circ} \mathrm{C}$. The ring coupons were then subjected to 50 shear cycles of a $9.8-\mathrm{kN}$ load and 25 shear cycles of a 14.7-kN load, followed by shear tests to failure. The thermal cycling and shear loading were conducted to simulate the anticipated duty cycles. The inertia-welded, $\mathrm{Re} / \mathrm{Nb}$-7.5Ta rings were found to have substantial margin (137 to $145 \mathrm{MPa}$ ultimate shear strength) to withstand the stresses induced by launch vibration and on-orbit firing.

Full-size, diffusion-bonded, $\mathrm{Re} / \mathrm{Ta}$ rings were found to be leak tight to $2 \mathrm{MPa}$. A diffusion-bonded, $\mathrm{Re} / \mathrm{Ta}$ ring was subjected to the same thermal cycling and shear loading as the inertia-welded ring and found to have $276 \mathrm{MPa}$ ultimate shear strength. As with the inertia-weld coupons, the diffusion-bonded ring had substantial margin to withstand launch vibration and on-orbit induced stresses.

Explosively-bonded, $\mathrm{Re} / \mathrm{Ta} / \mathrm{C} 103$ flat plates were found to have high strength (262 MPa ultimate shear strength) after being subjected to $2 \mathrm{hr}$ at $1370{ }^{\circ} \mathrm{C}$ and 30 thermal cycles of room temperature to $1370{ }^{\circ} \mathrm{C}$. Under a NASA Small Business Innovative Research program (ref. 11), three full-size, explosively-bonded, $\mathrm{Re} / \mathrm{Ta} / \mathrm{C} 103$ rings were fabricated, each using different joining parameters. The ring joined using nominal joining parameters was found to be leak tight to 
1.4 $\mathrm{MPa}$ (the other two rings were joined using lower energy joining parameters). At this writing, the explosively-bonded ring had not yet been evaluated in shear testing. These rings were fabricated to demonstrate the technique of joining with a $\mathrm{Ta}$ interlayer, however, the explosive bonding process could also be used to join $\mathrm{Re}$ to $\mathrm{Nb}-7.5 \mathrm{Ta}$ or pure $\mathrm{Ta}$.

\section{CONCLUDING REMARKS}

This paper discussed an on-going program examining two concerns associated with $\mathrm{Ir} / \mathrm{Re}$ engines: characterization of $\mathrm{Re}$ mechanical properties and the joining of $\operatorname{Re}$ to dissimilar metals. Samples of asreceived HIP PM Re were tensile tested at temperatures from 1370 to $2090{ }^{\circ} \mathrm{C}$. The samples retained high strength $(>70 \mathrm{MPa})$ at $2090^{\circ} \mathrm{C}$. Future testing will examine the behavior of annealed $\mathrm{Re}$ samples at elevated temperatures. Techniques for making transition pieces for the joining of $\mathrm{Re}$ chambers to $\mathrm{C} 103$ nozzle skirts were evaluated in shear testing. Flat plate, Re-to-C103 coupons, joined by explosive bonding and diffusion bonding, were found to retain high strength after being subjected to thermal cycling and thermal aging. The same was true for the EB welding of $\mathrm{Re}$ and/or $\mathrm{C} 103$ tabs to the coupons. The strength of these joint coupons only degraded after the combination of $\mathrm{C} 103 \mathrm{~EB}$ weld tabs and thermal cycling (100 cycles, from 100 to $\left.1100{ }^{\circ} \mathrm{C}\right)$. This combination apparently resulted in enough interdiffusion between $\mathrm{Re}$ and $\mathrm{Nb}$ to form an alloy that apparently weakened the joint. Re-to-C103 ring coupons joined by diffusion bonding were found to retain high strength after being subjected to thermal cycling and thermal aging. Full-size rings were evaluated by TRW under a NASA contract. Ring coupons of $\mathrm{Re}$ joined to a $\mathrm{Nb}-\mathrm{Ta}$ alloy by inertia welding and to $\mathrm{Ta}$ by diffusion bonding had high strength after being subjected to shear loading and thermal cycling. Explosively-bonded ring coupons of $\mathrm{Re}$-to-C103, with a Ta interlayer, were successfully fabricated but not tested at this writing.

\section{ACKNOWLEDGEMENTS}

The authors would like to express their deep appreciation for Robert Titran of the Materials
Division at NASA Lewis Research Center and Don Mittendorf of AlliedSignal, Fluid Systems Division for their efforts in conducting the high temperature tensile testing. The authors would also like to express their gratitude to Douglas Wolf of the University of Dayton for the testing and evaluation of the joint coupons.

\section{REFERENCES}

1. Schneider, S.J.: Low Thrust Chemical Rocket Technology, NASA TM-105927, IAF Paper 92-0669, September 1992.

2. Schoenman, L: $4000^{\circ} \mathrm{F}$ Materials for Low Thrust Rocket Engines, AIAA Paper 93-2406, June 1993.

3. Biaglow, J.A.: Rhenium Material Properties, NASA TM-107043, AIAA Paper 95-2398, July 1995.

4. Reed, B.D. and Morren, S.H.: Evaluation of Rhenium Joining Methods, NASA TM-107055, AIAA Paper 95-2397, July 1995.

5. Reed. B.D. and Dickerson, R.: Testing of Electroformed Deposited Iridium/Powder Metallurgy Rhenium Rockets, NASA TM-107172, 1995 JANNAF Propulsion Meeting, December 1995.

6. Wooten, J.R. and Lansaw, P.T.: HighTemperature, Oxidation-Resistant Thruster Research, Final Report, Contract NAS3-24643, CR-185233, February 1990.

7. Chazen, M.L., etc. al.: Space Storable Rocket Technology Program, Option 1 Final Report, Contract NAS3-26246, CR-191171, August 1993.

8. Jassowski, D.M.: Advanced Small Rocket Chambers, Option 3 Final Report, Contract NAS3-25646, CR-195435, November 1994.

9. Personal Communication with Douglas Wolf, University of Dayton.

10. Chazen, M.L., etc. al.: Space Storable Rocket Technology Program, Option 2 Final Report, Contract NAS3-26246, to be published.

11. Butler, D.J.: Creating Next Generation HighTemperature Materials with ExplosivelyWelded Refractory Metals, Contract NAS3-26928, Phase II Final Report, May 1996. 
TABLE 1-TENSILE DATA FOR AS-RECEIVED HIP PM Re

\begin{tabular}{|c|c|c|c|c|c|}
\hline Specimen & $\begin{array}{c}\text { Temperature, } \\
{ }^{\circ} \mathrm{C}\end{array}$ & $\begin{array}{c}0.2 \text { percent } \\
\text { yield strength, } \\
\mathrm{MPa}\end{array}$ & $\begin{array}{c}\text { Ultimate } \\
\text { strength, } \\
\mathrm{MPa}\end{array}$ & $\begin{array}{c}\text { Percent } \\
\text { reduction } \\
\text { of area }\end{array}$ & $\begin{array}{c}\text { Percent } \\
\text { elongation }\end{array}$ \\
\hline HIP PM (NASA) & 1370 & 208 & 217 & 7.9 & 9.1 \\
\cline { 2 - 6 } & 1370 & 211 & 220 & 7.5 & 12.3 \\
\cline { 2 - 6 } & 1860 & 105 & 113 & 13.0 & 17.0 \\
\cline { 2 - 6 } & 1925 & 87.6 & 98.2 & 13.7 & 11.5 \\
\cline { 2 - 6 } & 1925 & 78.1 & 92.5 & 10.2 & 27.0 \\
\cline { 2 - 6 } & 2090 & 71.0 & 80.2 & 12.7 & 16.6 \\
\hline HIP PM (Allied) & 1370 & 171 & 202 & 9.4 & 16.2 \\
\cline { 2 - 6 } & 1370 & 173 & 198 & 12.8 & 13.1 \\
\cline { 2 - 6 } & 1510 & 143 & 151 & 11.1 & 16.3 \\
\cline { 2 - 7 } & 1510 & 138 & 150 & 10.2 & 15.8 \\
\cline { 2 - 7 } & 1650 & 104 & 111 & 14.4 & 13.9 \\
\cline { 2 - 6 } & 1650 & 101 & 107 & 12.3 & 8.3 \\
\cline { 2 - 7 } & 1925 & 67.4 & 73.0 & 12.4 & 15.5 \\
\cline { 2 - 7 } & 1925 & 78.8 & 79.4 & 12.5 & 18.0 \\
\hline
\end{tabular}

TABLE II.-SUMMARY OF EXPLOSIVE BONDING, Re-TO-C103 JOINT EVALUATION

\begin{tabular}{|c|c|c|c|}
\hline Joint coupon & $\begin{array}{c}\text { Heat } \\
\text { treatment }\end{array}$ & EB weld tab & $\begin{array}{l}\text { Ultimate shear } \\
\text { strength, } \\
\mathrm{MPa}\end{array}$ \\
\hline \multirow[t]{12}{*}{ Flat plate, lot $\# 2090$} & None & None & 310 \\
\hline & None & None & 281 \\
\hline & None & None & 468 \\
\hline & None & None & 463 \\
\hline & Cycled* & None & 219 \\
\hline & Cycled* & None & 466 \\
\hline & Cycled* & $\operatorname{Re}$ & 212 \\
\hline & Cycled* & $\mathrm{C} 103$ & 53.8 \\
\hline & Cycled* & $\mathrm{C103}$ & 114 \\
\hline & Cycled* & $\operatorname{Re} \& C 103$ & 24.1 \\
\hline & None & $\operatorname{Re}$ & 210 \\
\hline & None & C103 & 403 \\
\hline \multirow{13}{*}{$\begin{array}{l}\text { Flat plate, lot \#2097 (lower energy } \\
\text { parameters) }\end{array}$} & None & None & 223 \\
\hline & None & None & 162 \\
\hline & None & None & 130 \\
\hline & None & None & 165 \\
\hline & Cycled ${ }^{2}$ & None & 246 \\
\hline & Cycled $^{2}$ & None & 94.5 \\
\hline & Cycled $^{2}$ & $\operatorname{Re}$ & 231 \\
\hline & Cycled $^{2}$ & $\overline{R e}$ & 57.2 \\
\hline & Cycled & $\mathrm{C} 103$ & 75.8 \\
\hline & Cycled $^{2}$ & $\mathrm{Re} \& \mathrm{C} 103$ & 26.2 \\
\hline & None & $\mathbf{R e}$ & 121 \\
\hline & None & $\mathrm{C103}$ & 252 \\
\hline & None & $\mathrm{C103}$ & 178 \\
\hline
\end{tabular}

${ }^{\mathrm{a}} 100$ cycles, room temperature to $1100^{\circ} \mathrm{C}$. 
TABLE III.-SUMMARY OF DIFFUSION BONDING, Re-TO-C103 JOINT EVALUATION

\begin{tabular}{|c|c|c|c|}
\hline $\begin{array}{l}\text { Joint } \\
\text { coupon }\end{array}$ & Heat treatment & EB weld tab & $\begin{array}{c}\text { Ultimate } \\
\text { shear } \\
\text { strength, } \\
\mathrm{MPa}\end{array}$ \\
\hline \multirow[t]{12}{*}{ Flat plate } & None & None & 199 \\
\hline & None & None & 348 \\
\hline & None & None & 318 \\
\hline & Cycled $^{2}$ & None & 87.6 \\
\hline & Cycled $^{3}$ & $\overline{\operatorname{Re}}$ & 155 \\
\hline & Cycled $^{a}$ & $\mathrm{C} 103$ & 29.0 \\
\hline & Cycled $^{2}$ & $\mathrm{Cl03}$ & 340 \\
\hline & Cycled $^{2}$ & $\mathrm{Re} \& \mathrm{C} 103$ & 82.7 \\
\hline & None & $\mathrm{C} 103$ & 247 \\
\hline & None & $\mathrm{C103}$ & 161 \\
\hline & $3 \mathrm{hrs} @ 1100^{\circ} \mathrm{C}$ & None & 122 \\
\hline & $6 \mathrm{hrs} @ 1100^{\circ} \mathrm{C}$ & None & 134 \\
\hline \multirow[t]{6}{*}{ Ring } & None & None & 710 \\
\hline & None & None & 670 \\
\hline & None & None & 541 \\
\hline & Cycled $^{2}$ & None & 965 \\
\hline & Cycled $^{2}$ & None & 583 \\
\hline & $6 \mathrm{hrs} @ 1100^{\circ} \mathrm{C}$ & None & 1096 \\
\hline
\end{tabular}

${ }^{\mathrm{a}} 100$ Cycles, room temperature to $1100^{\circ} \mathrm{C}$.

TABLE IV - SUMMARY OF TRW Re JOINT EVALUATION

\begin{tabular}{|c|c|c|}
\hline Joint coupon & Heat treatment & $\begin{array}{c}\text { Ultimate } \\
\text { shear } \\
\text { strength, } \\
\mathrm{MPa}\end{array}$ \\
\hline \multicolumn{3}{|c|}{ Inertia weld coupons } \\
\hline \multirow[t]{2}{*}{$\mathrm{Re} / \mathrm{Nb}-7.5 \mathrm{Ta}$, rod } & None & 469 \\
\hline & $2 \mathrm{hrs} @ 1370^{\circ} \mathrm{C}$ & 299 \\
\hline $\begin{array}{l}\mathrm{Re} / \mathrm{Nb}-7.5 \mathrm{Ta} \text {, rod (joined whlower } \\
\text { energy parameters) }\end{array}$ & $2 \mathrm{hrs} @ 1370^{\circ} \mathrm{C}$ & 265 \\
\hline \multirow[t]{3}{*}{$\mathrm{Re} / \mathrm{Nb}-7.5 \mathrm{Ta}$, ring ${ }^{\mathrm{a}}$} & None & 259 \\
\hline & $\begin{array}{l}2 \mathrm{hrs} @ 1370^{\circ} \mathrm{C} \& 30 \\
\text { cycles, RT to } 1370^{\circ} \mathrm{C}\end{array}$ & 145 \\
\hline & $\begin{array}{l}2 \mathrm{hrs} @ 1370{ }^{\circ} \mathrm{C} \& 30 \\
\text { cycles, RT to } 1370^{\circ} \mathrm{C} \\
\end{array}$ & 137 \\
\hline \multicolumn{3}{|c|}{ Diffusion bond coupon } \\
\hline $\operatorname{Re} / \mathrm{Ta}$, ring & 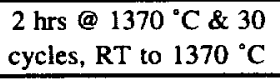 & 276 \\
\hline \multicolumn{3}{|c|}{ Explosive bond coupons } \\
\hline \multirow[t]{2}{*}{$\mathrm{Re} / \mathrm{Ta} / \mathrm{C} 103$, flat plate } & None & 545 \\
\hline & $\begin{array}{l}2 \mathrm{hrs} @ 1370{ }^{\circ} \mathrm{C} \& 30 \\
\text { cycles, RT to } 13700^{\circ} \mathrm{C}\end{array}$ & 262 \\
\hline
\end{tabular}

${ }^{\mathrm{a}}$ Ring coupons were subjected to 50 shear cycles of a $9.8-\mathrm{kN}$ load and 25 shear cycles of a $14.7-\mathrm{kN}$ load. The coupons were then shear tested to failure. 


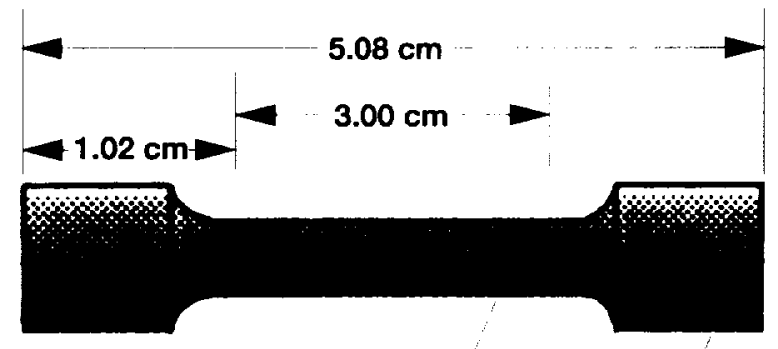

$.320 \mathrm{~cm}$ diameter $+.008 \mathrm{~cm}$

$645 \mathrm{~cm}$ diameter

$+/-.013 \mathrm{~cm}$

typical each grip

Figure 1.-Re tensile bar configuration.

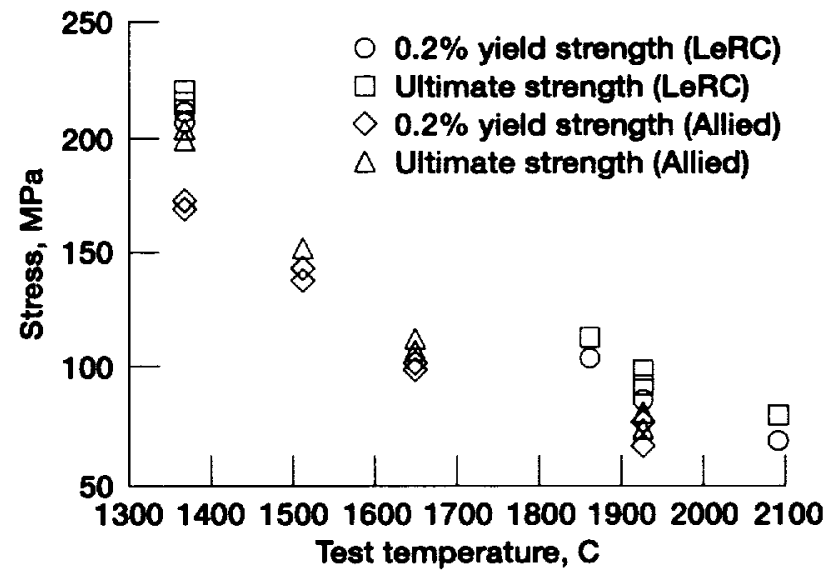

Figure 2.-Tensile strength for HIP PM Re at elevated temperature.
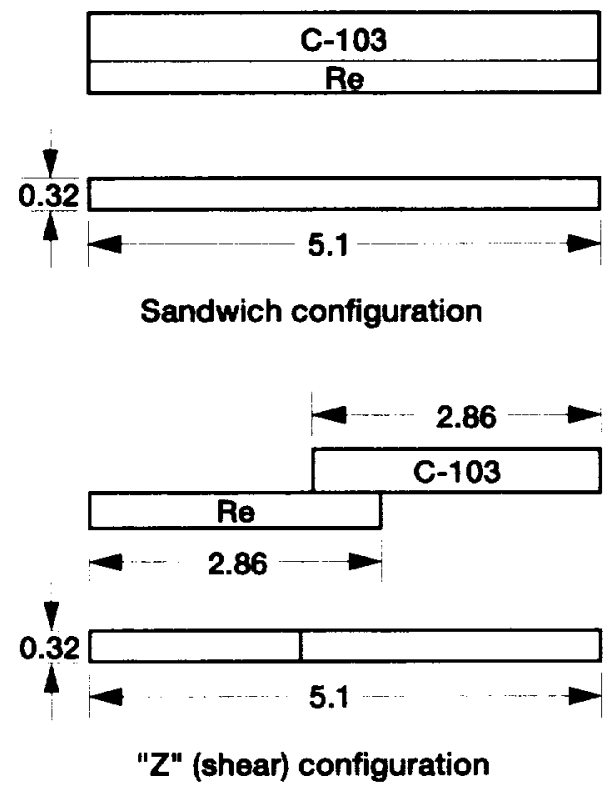

Figure 3.-Flat plate coupon configuration. Dimensions in centimeters.

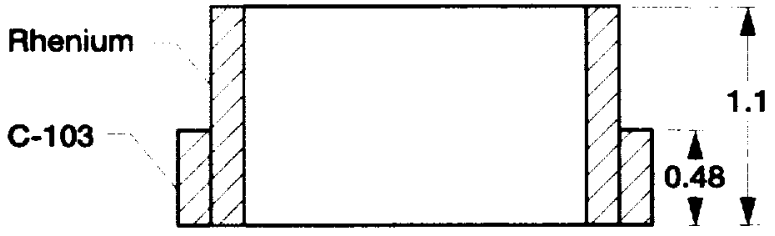

Figure 4.-Tubular coupon configuration. Dimensions in centimeters.

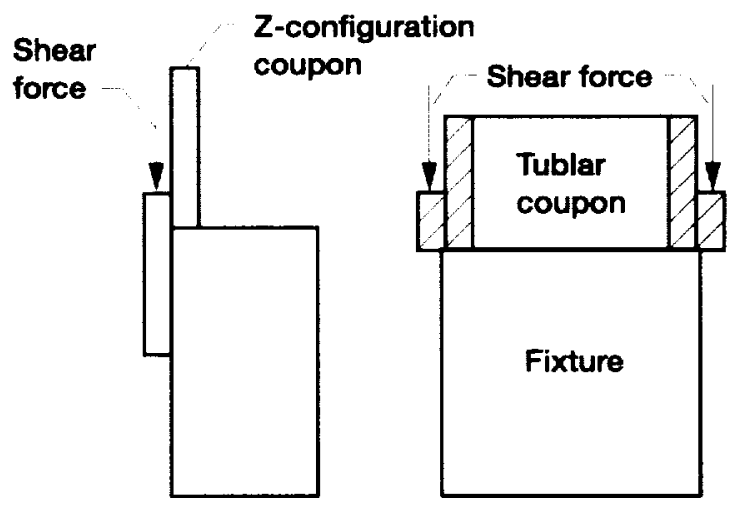

Figure 5.-Shear testing of joint coupons.

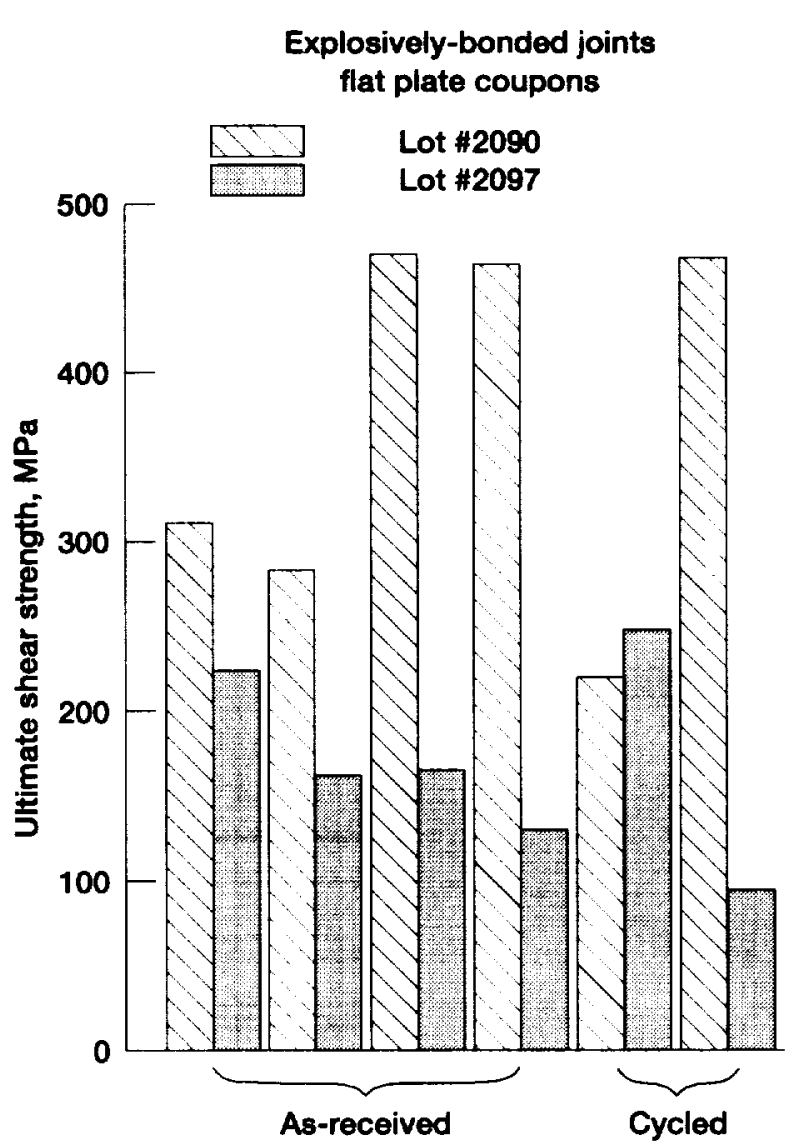

Figure 6.-Comparison of as-received and cycled, explosive bond coupons. 


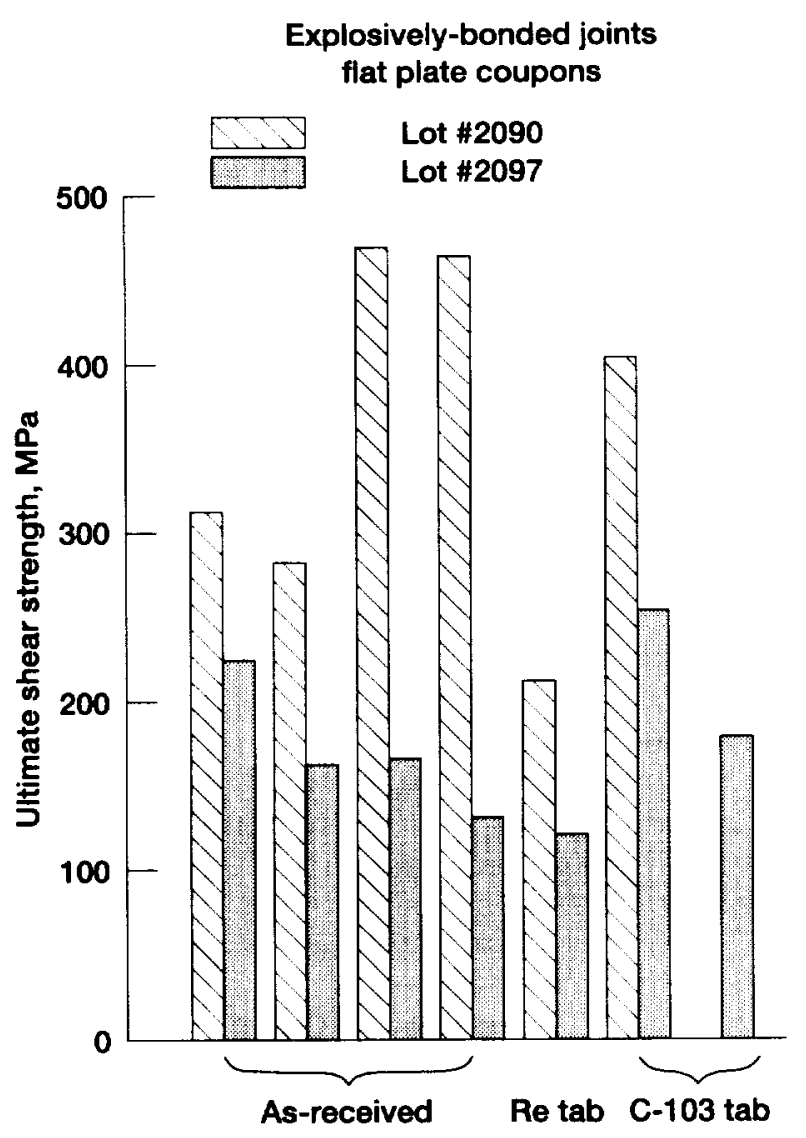

Figure 7.-Comparison of as-received and EB weld tab, explosive bond coupons.

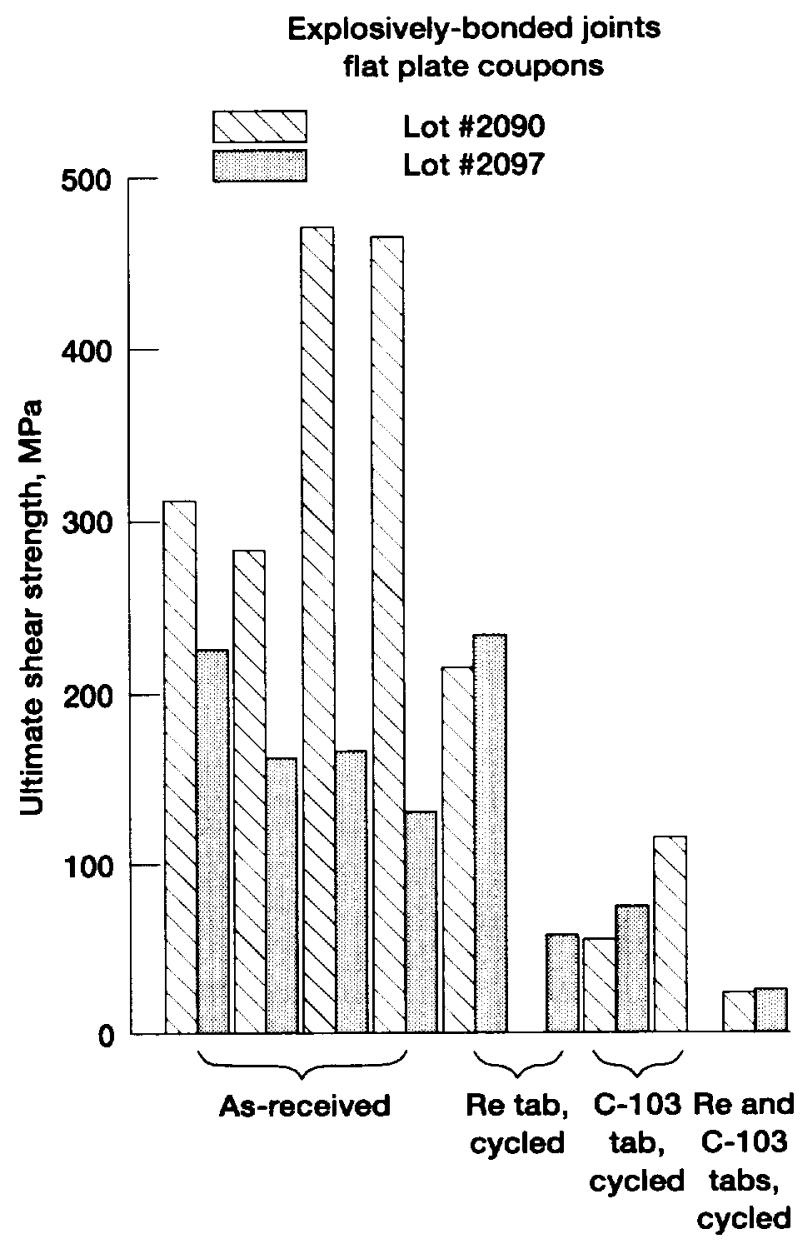

Figure 8.-Comparison of as-received and EB weld tab + cycled, explosive bond coupons. 


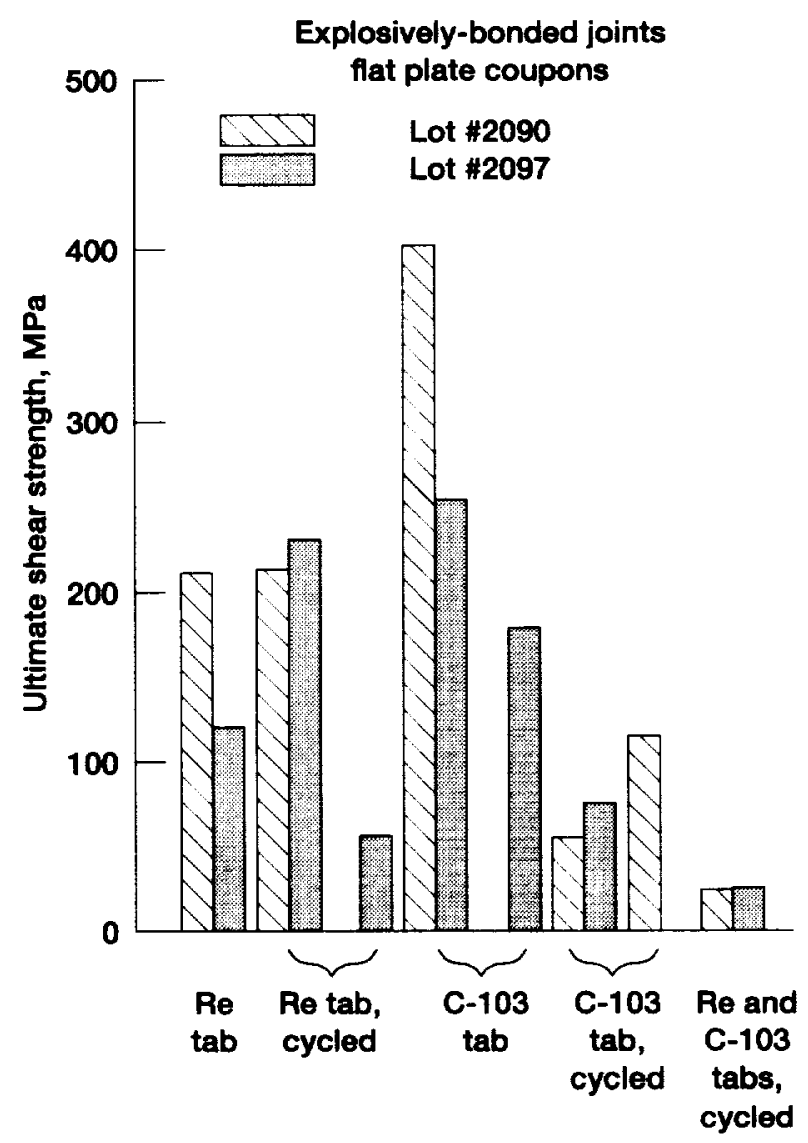

Figure 9.-Comparison of EB weld tab and EB weld tab + cycled, explosive bond coupons.

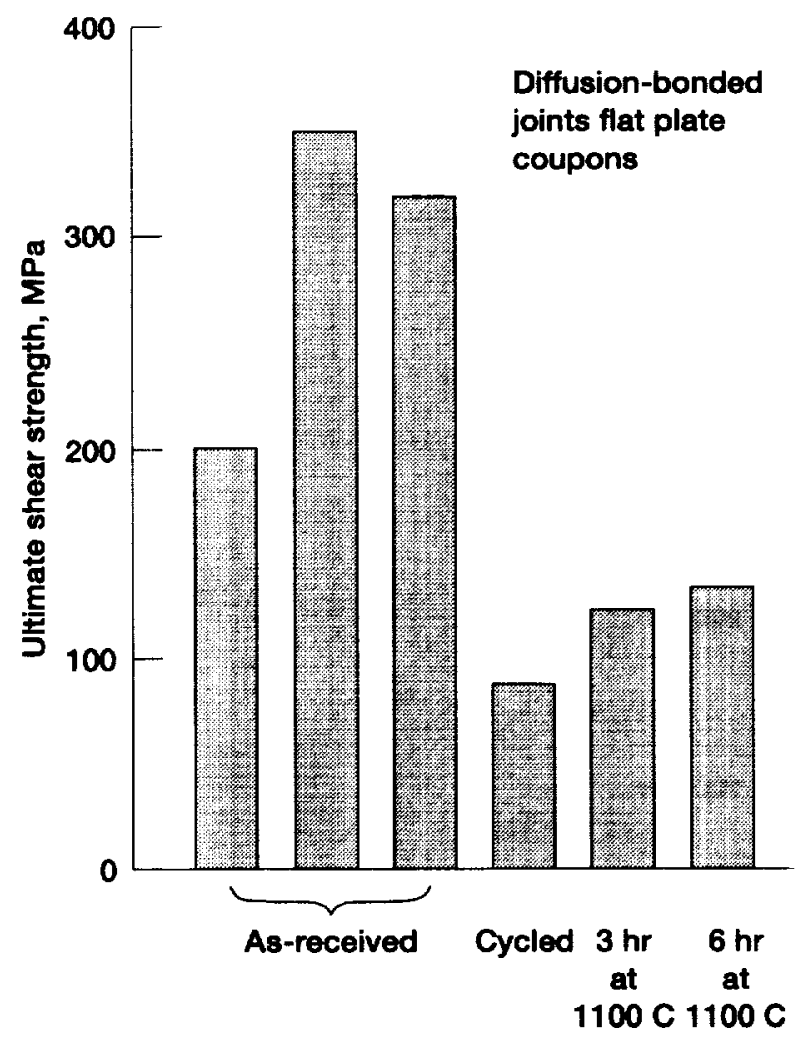

Figure 10.-Comparison of as-received, and aged diffusion bond coupons. 


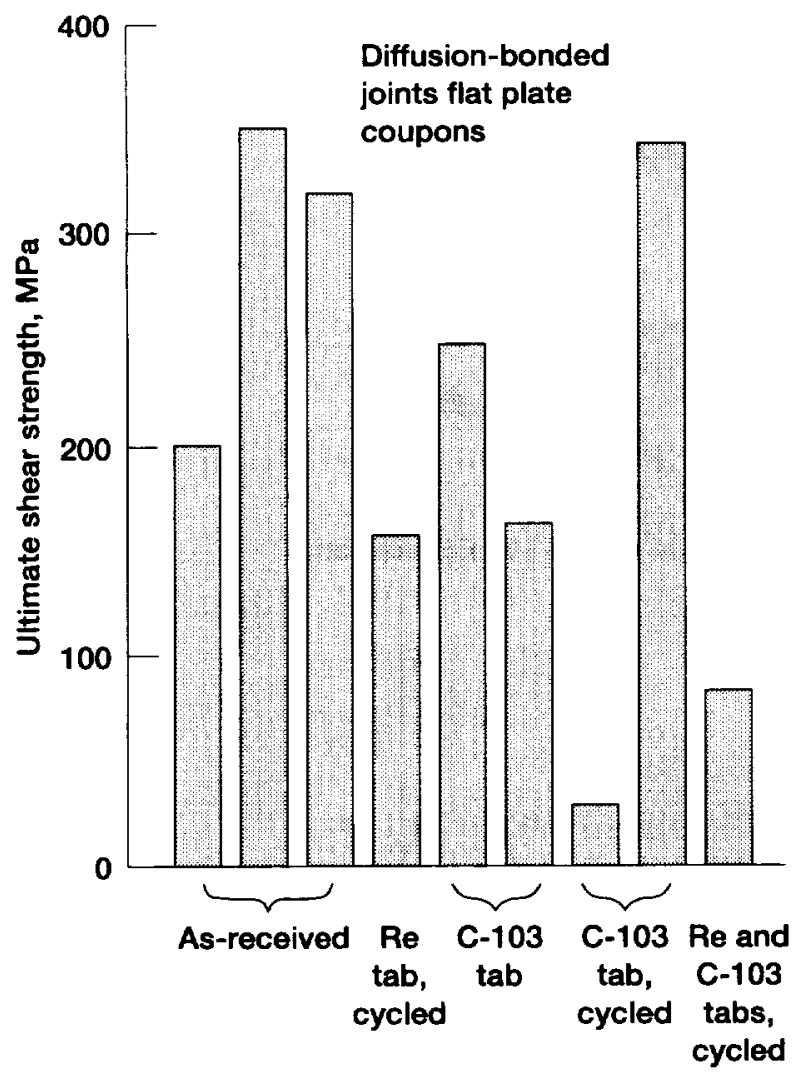

Figure 11.-Comparison of as-received, EB weld tab and $\mathrm{EB}$ weld tab + cycled, diffusion bond coupons.

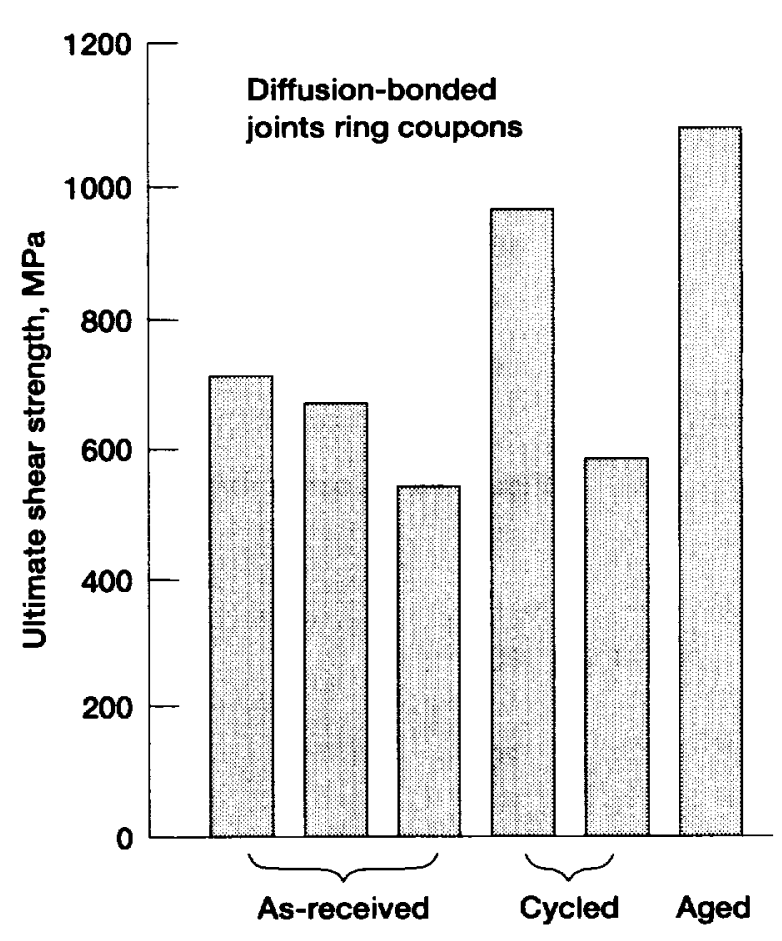

Figure 12.-Comparison of tubular diffusion bond coupon. 


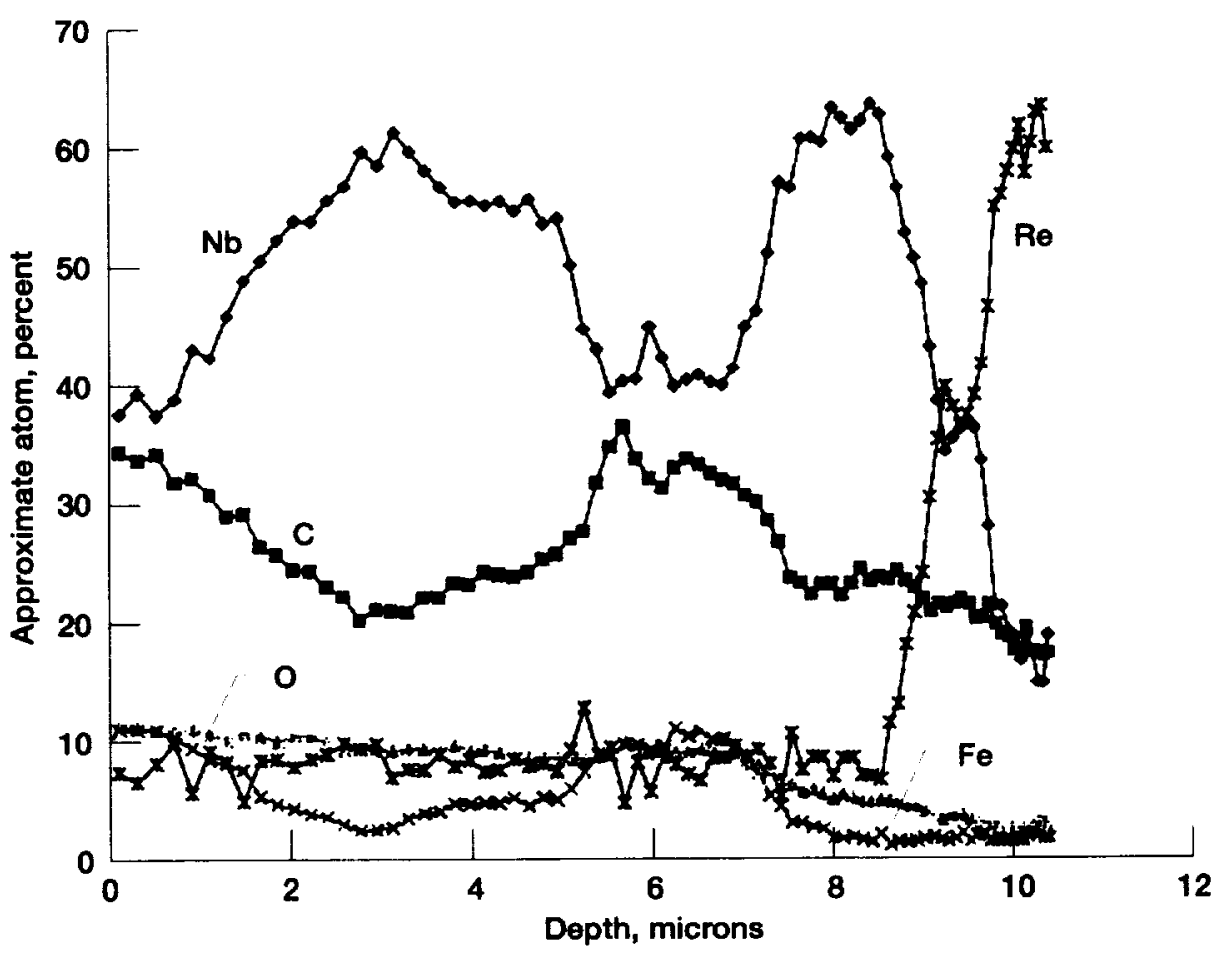

Figure 13.-Depth profile of explosively-bonded coupon with C-103 EB weld tab.

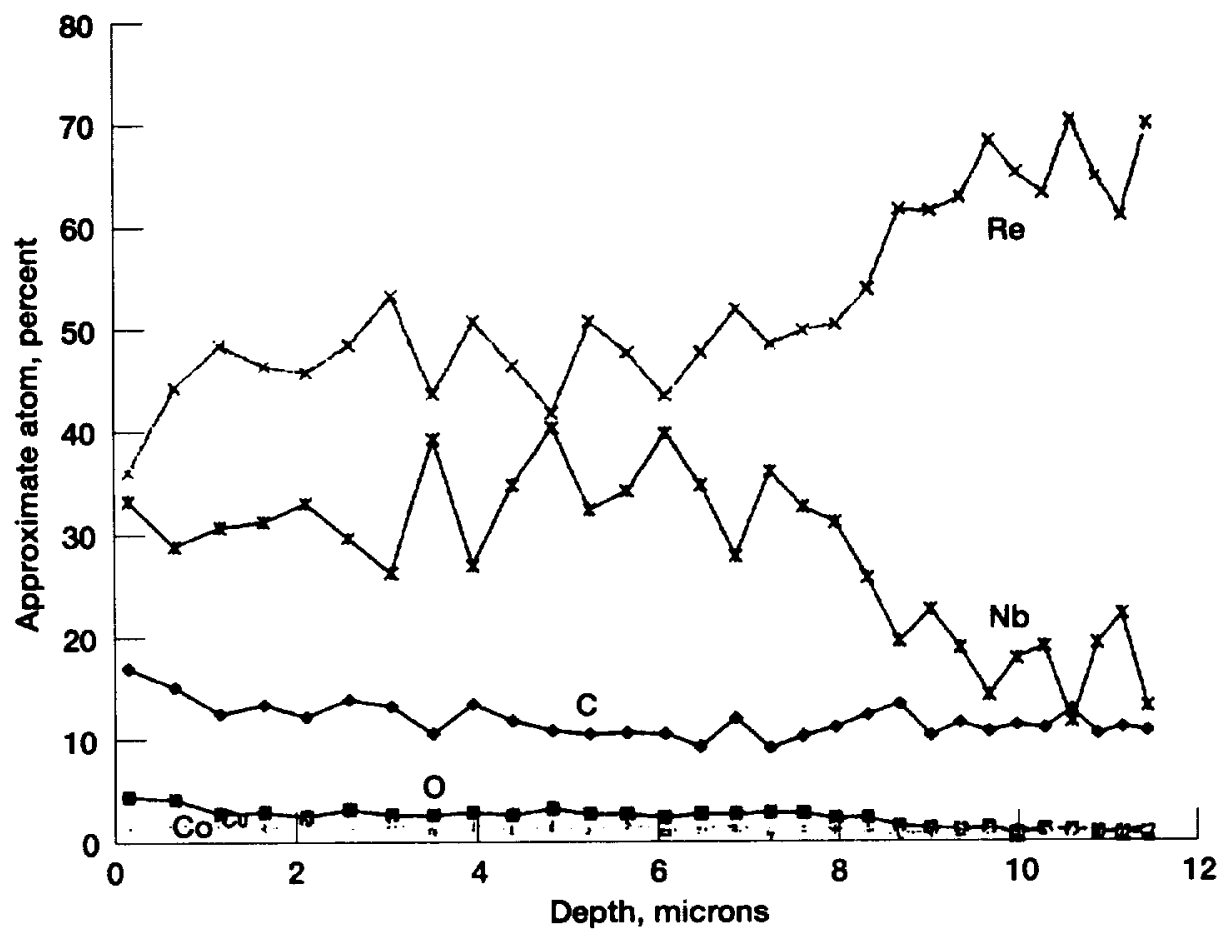

Figure 14.-Depth profile of explosively-bonded coupon with C-103 EB weld tab and subjected to thermal cycling. 
Public reporting burden for this collection of information is estimaled to average 1 hour per response, including the time for reviowing instnuctions. searching exiating data sources, ganhering and maintaining the data needed, and completing and reviewing the collection of information. Send comments regarding this bunden estimate or any other aspect of this , Washingtion Headquarters Services. Directorate for Information Operations and Reports, 1215 Jutles Davis Highway, Suite 1204. Arlington, VA 22202-4302, and to the Oflice of Management and Budget, Paperwork Reduction Project (0704-018B), Washington, DC 20503.

\begin{tabular}{|l|c|c|}
\hline 1. AGENCY USE ONLY (Leave blank) & $\begin{array}{c}\text { 2. AEPORT DATE } \\
\text { December } 1996\end{array}$ & $\begin{array}{r}\text { 3. REPORT TYPE AND DATES COVERED } \\
\text { Technical Memorandum }\end{array}$
\end{tabular}

\section{TITLE AND SUBTITLE}

Rhenium Mechanical Properties and Joining Technology

\section{FUNDING NUMBERS}

Brian D. Reed and James A. Biaglow

WU-242-70-02

7. PERFORMING ORGANIZATION NAME(S) AND ADDRESS(ES)

National Aeronautics and Space Administration

Lewis Research Center

Cleveland, Ohio 44135-3191
B. PERForming ORganization REPORT NUMBER

E-10413

10. SPONSORINGMONITORING AGENCY REPORT NUMBER

NASA TM-107317

AIAA-96-2598

National Aeronautics and Space Administration

Washington, D.C. 20546-0001

\section{SUPPLEMENTARY NOTES}

Prepared for the 32nd Joint Propulsion Conference cosponsored by AIAA, ASME, SAE, and ASEE, Lake Buena Vista, Florida, July 1-3, 1996. Responsible person, Brian D. Reed, organization code 5330, (216) 977-7489.

12a. DISTRIBUTIONAVAILABILITY STATEMENT

12b. DISTRIBUTION CODE

Unclassified - Unlimited

Subject Category 20

This publication is available from the NASA Center for AeroSpace Information, (301) 621-0390.

13. ABSTRACT (Maximum 200 words)

Iridium-coated rhenium (Ir/Re) provides thermal margin for high performance and long life radiation cooled rockets. Two issues that have arisen in the development of flight $\mathrm{Ir} / \mathrm{Re}$ engines are the sparsity of rhenium $(\mathrm{Re})$ mechanical property data (partic ularly at high temperatures) required for engineering design and the inability to directly electron beam weld Re chambers to $\mathrm{C} 103$ nozzle skirts. To address these issues, a Re mechanical property database is being established and techniques for creating Re/ C103 transition joints are being investigated. This paper discusses the tensile testing results of powder metallurgy Re samples at temperatures from 1370 to $2090^{\circ} \mathrm{C}$. Also discussed is the evaluation of $\mathrm{Re} / \mathrm{C} 103$ transition pieces joined by both, explosive and dif fusion bonding. Finally the evaluation of full size $\operatorname{Re}$ transition pieces, joined by inertia welding, as well as explosive and diffusion bonding, is detailed.

\section{SUBJECT TERMS}

Rhenium; Iridium; Radiation-cooled rockets; Mechanical properties; Joining

16. PRICE CODE

$$
\mathrm{A03}
$$

17. SECURITY CLASSIFICATION
OF REPORT
Unclassified

NSN 7540-01-280-5500
18. SECURITY CLASSIFICATION OF THIS PAGE Unclassified
19. SECURITY CLASSIFICATION OF ABSTRACT Unclassified

20. LIMITATION OF ABSTRACT

Standard Form 298 (Rev. 2-89) Prescribed by ANSI Std. Z39-18 298-102 
